\title{
Traceability: Availability and Efficiency among Food Industries in Ghana
}

\author{
Patricia Foriwaa Ababio, Doreen Dedo Adi, Vida Commey
}

Technology Department, University of Education Winneba, Kumasi, Winneba.

Email: sampat34j@yahoo.co.uk

Received November $21^{\text {st }}, 2012$; revised December $27^{\text {th }}, 2012$; accepted January $4^{\text {th }}, 2013$

\begin{abstract}
Food traceability systems availability and efficiency was investigated using 74 food businesses along the food chain in Ghana. Questionnaire with closed and open ended questions were given to purposefully sampled staff in key positions in the food businesses to answer on qualification of technical personnel, availability of documentation procedure and how these businesses were controlling traceability systems. Most food businesses were using Higher National Diploma graduates in the technical/supervisory positions. Documentation was poor and although there was awareness on traceability across the food businesses, implementation and maintenance was not effective. Only $23.8 \%$ manufacturing/processing units, $20 \%$ hospitals, $16.7 \%$ hotels and $14.8 \%$ schools could complete traceability test within 4 hours. It was recommended that more short training programmes on quality and safety be designed for workers in the food industry by appropriate institutions while science students from the Senior High Schools are encouraged to enroll on food science and food manufacturing technology programs to improve on the current situation.
\end{abstract}

Keywords: Food; Traceability; Legislation; Quality Assurance

\section{Introduction}

Food accessibility worldwide has improved over the decade but with increased complexity. The chain that food passes through include agricultural production and harvesting, holding and storing of raw materials, food manufacturing, transportation and distribution, retailing, food service and food preparation in various homes [1]. Quality assurance and safety control systems are necessary throughout the chain $[2,3]$ and food manufactures and processors including those in the service industry are required by law to have the necessary information from their supplier that indicates compliance [4] and safety status of the raw materials being supplied and after production produce distributed are equally to be recorded so as to be able to follow the product a "step up" $[5,6]$.

Traceability is a system implemented as part of management plan in ensuring a food operation has the capability to trace product externally and internally as applicable [7]. It is a system designed to keep record on products or product attributes through the supply chain [2]. Establishing traceability system by food and feed operators is to meet legislative requirements in most countries including European Union, United states and Japan and also existing Quality Management systems like BRC, ISO 22000, HACCP, GMP, SQF, FSSC 22000, IFIS, Global GAP $[2,8]$. This goes to prove that operators can identity and trace their raw materials received, have the ability to identity and trace what, when and how the raw material was handled, identify and trace where the finished product was sent and have the available and efficient document and record on this.

Traceability is a legislative requirement internationally and it shows that there are measures in place to strengthen consumer protection against both safety and quality errors including allergen contamination and genetically modified food products. There is advancement in technologies internationally to automatically detect deviations and non conformances for effective alerting methods towards preventing the risk of recalls and losses related with customer complaints, identified internal non conformances and regulatory problems along the food chain. Thus reducing the unlimited food destroyed during food borne disease outbreaks, allowing uncontaminated food to be marketed and also the manual entries and records used by many $[2,9]$.

The food industry in Ghana is growing with increased small and medium scale industries springing up to support the limited number of large manufacturers in the sector [10]. To ensure food quality and safety control with limited liability on the manufacturer, standards are to be required from customers who receive products from both internal and external suppliers. This ensures that 
customers (manufacturers and processers, retailers and other food services) can ascertain the quality and safety of their raw materials and can also ensure effective recall to avoid identified food hazards from causing harm after products have been dispatched. The Ghana Government's Trade Policy for January 2006-December 2010 included the need to develop measures with clear and sufficient rules on consumer protection of which food safety systems with traceability could not be left out. A preliminary study by Ababio and Adi showed that most food handlers depended on the open market for sourcing of their raw materials for food preparation [11]. Raw material purchasing was essentially based on visual acceptability and cost. Food processing companies are reported to be overlooking self inspection, documentation and record keeping [12]. There is also currently limited publication on traceability management availability and its effectiveness along the food chain. Sefa-Dede, reported during Go-Global conference in Accra of the lack of traceability in the food supply chain $[13,14]$. The researchers set out to evaluate traceability availability and effectiveness along the food chain in Ghana.

\section{Methodology}

One hundred and fifty (150) questionnaires with closed and open ended questions were designed for the manufacturing and service industries in 3 cities in the Country. From Figure 1, areas selected were Accra of the Greater Accra Region, Kumasi in Ashanti Region and Ho in Volta Region. Questions were put into three categories Section A for information about the set ups including kind of set up, ownership, number of years in operation among others. Section B consisted of management commitment requirements in terms of available quality management systems and qualification of persons responsible. Section $\mathrm{C}$ was on management commitment to auditing and traceability and how it is maintained.

The sampling plan used was purposive as only the

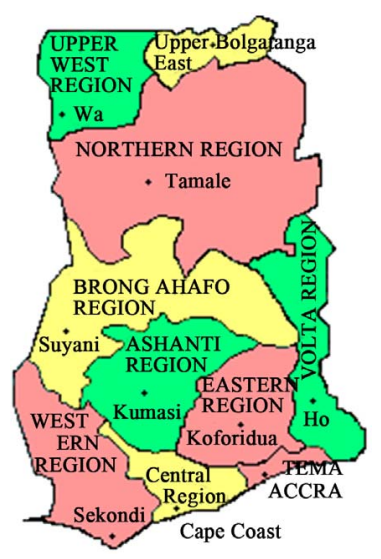

Figure 1. Map of Ghana showing regions [15]. food setups alone could furnish the researcher with the relevant information needed and snow balled as most food managers were not willing to give out information and the researcher in some cases had to use people who knew each other in the industry as a means of connecting to various set ups. Some manufacturers requested for formal introductory letter from the researcher's university which was received and given to personnel on request. This took about three months to retrieve as most respondents preferred completing the questionnaire at their own pace. Out of the 150 questionnaires dispatched $49 \%$ was available for use as some were not returned, others were not willing to participate and some were with errors which the researcher could readily identity and hence were discarded. Data analysis was by the use of Statistical Package for Social Sciences version 16 to report on distribution of respondents, the existing correlation between variables and Chi square to find the significance of their association at $95 \%$ confidence level.

\section{Results and Discussion}

\subsection{Demographic Information on Food Businesses}

From Table 1 schools represented the highest sampled unit in the research constituting $36.5 \%$ of the whole sample size followed by manufacturers/food processors, restaurants and hospitals had equivalent presentation with hotels being the least presented. Whiles half of schools and hospitals represented had been in operation for over 20 years, restaurants and manufacturing/processing companies were quite young with $40 \%$ of restaurant still within their first 5 years in operation and none from 20 years and above. Manufacturing/processing companies had over $90 \%$ representation of younger units below the age of 20 whiles $50 \%$ of hotels had been in operation for 5 to 10 years.

Thus commercial food services in the country seem to be quite young as compared to the welfare or institutional services. All sectors had higher presentation on availability of staff in the technical or supervisory role to ensure that hygiene practices are in place which is in compliance with national law, 1992 Food and Drugs Act of the PNDCL 3058 and international law, Food Safety Act 1990 of the United Kingdom on the availability of persons with supervisory role $[11,16]$. Although there was no significant difference in the availability of technical staff/supervisors in the various businesses, food manufacturers/processors featured highest in businesses without technical staff or supervisors. These could be small scale businesses normally called "cottage" which are sometimes operated by individuals or families without any technical background. Personnel development and training in the area of formal education was not signifi- 
Table 1. Type of food business, years in operation and key food safety personnel qualification.

\begin{tabular}{|c|c|c|c|c|c|c|}
\hline & & \multicolumn{4}{|c|}{ Type of Food Business } & \multirow[t]{2}{*}{ Chi Square } \\
\hline & Hotel & Restaurant & Manufacturers/processors & Hospitals & Schools & \\
\hline Percentage of food set up & 8.1 & 13.5 & 28.4 & 13.5 & 36.5 & $19.743(0.072)$ \\
\hline \multicolumn{7}{|l|}{ Number of years in business } \\
\hline $1-5$ & 0 & 40.0 & 28.6 & 0 & 0 & $34.461(0.072)$ \\
\hline $5-10$ & 50.0 & 30.0 & 33.3 & 30.0 & 30.0 & \\
\hline $11-20$ & 33.3 & 30.0 & 28.6 & 20.0 & 20.0 & \\
\hline$>20$ & 16.7 & 0 & 9.5 & 50.0 & 50.0 & \\
\hline \multicolumn{7}{|l|}{$\begin{array}{l}\text { Availability of technical } \\
\text { person/supervisor }\end{array}$} \\
\hline Yes & 100 & 100 & 76.2 & 100 & 88.9 & $6.834(0.145)$ \\
\hline No & 0 & 0 & 23.8 & 0 & 11.1 & \\
\hline \multicolumn{7}{|l|}{$\begin{array}{l}\text { Qualification of technical } \\
\text { person/supervisor }\end{array}$} \\
\hline HND & 50.0 & 50.0 & 33.3 & 70.0 & 33.3 & $10.877(0.539)$ \\
\hline Degree & 50.0 & 40.0 & 52.4 & 20.0 & 59.3 & \\
\hline Second degree & 0 & 10.0 & 4.8 & 10.0 & 0 & \\
\hline None & 0 & 0 & 9.5 & 0.0 & 7.4 & \\
\hline \multicolumn{7}{|c|}{$\begin{array}{l}\text { Hygiene certification of technical } \\
\text { persons/supervisor }\end{array}$} \\
\hline Yes & 66.7 & 90.0 & 57.1 & 80.0 & 70.3 & $4.086(0.394)$ \\
\hline No & 33.3 & 10.0 & 42.9 & 20.0 & 29.7 & \\
\hline
\end{tabular}

cant across the various businesses although graduates with Higher National Diplomas were mostly employed for such positions across the sectors. First degree holders were mostly in the schools and manufacturing/processing companies as technical staff/supervisors. Hygiene quailfication which is a regulatory requirement for persons in technical or supervisory roles, was predominant in the restaurants $[5,15]$. This could be due to frequent visits and surveillance by the food inspectors from the various agencies across the country to small scale businesses. Eighty percent $(80 \%)$ of the hospitals sampled had hygiene trained staff in charge of food handling supervision. Food Manufacturers and processors had the highest number of supervisors without hygiene certificates confirming reported low standards by a member of the Food and Drugs Board [12]. As mentioned earlier most of these could be individuals or "one man" businesses (small scale businesses) who operates in less obvious environments obscured from the inspectorate focus.

\subsection{Management Commitment towards Documentation, Auditing and Traceability}

One of the management responsibilities towards consumer safety and legislative requirement compliance is the setting up of monitoring and auditing procedures and systems to verify ongoing processes to ascertain food safety and quality maintenance. All accredited certification bodies with food quality management systems re- quire the commitment of management to verify and validate processes [8]. From Table 2 there is no significant difference in the availability or maintenance of documentation across the businesses.

Documents serve as sources of information that management can fall on during auditing and training, they also serve as due diligence during legal disputes and customer complaints. Hotels had the highest percentage $(66.7 \%)$ on record keeping businesses followed by hospitals $(60.0 \%)$ and then food manufacturers with $47.6 \%$. Schools and restaurants had the highest values on record keeping non compliance. Lack of commitment in this area is reflected in the question on routine auditing in place. Restaurants have the highest figure $(60.7 \%)$ for no routine auditing followed by manufacturing and processing businesses then schools. Although 33.3\% of hotels had no written document there was auditing in place and this was done mostly once in a year. This is likely to be a one year visit by inspecting agencies to these facilities. Restaurants had the highest percentage $(40 \%)$ on businesses that never did any auditing. The auditing frequency across the businesses was not significant.

The ability to maintain information on raw materials through processing effectively such that businesses can trace their products one step down and one step up [2,7], requires putting systems in place (traceability procedure inclusive) and training quality assurance personnel to maintain it. From Table 3 the availability of traceability 
Table 2. Auditing commitment.

\begin{tabular}{|c|c|c|c|c|c|c|}
\hline & \multicolumn{5}{|c|}{ Type of Business } & \multirow[t]{2}{*}{ Chi Square } \\
\hline $\begin{array}{l}\text { Availability of } \\
\text { documentation }\end{array}$ & Hotel & Restaurant & Manufacturing/Processing & Hospital & School & \\
\hline Yes & 66.7 & 30.0 & 47.6 & 60.0 & 33.3 & $4.444(0.349)$ \\
\hline No & 33.3 & 70.0 & 52.4 & 40.0 & 66.7 & \\
\hline \multicolumn{7}{|c|}{ Routine auditing in place } \\
\hline Yes & 83.3 & 40.0 & 52.4 & 90.0 & 59.3 & $7.323(0.120)$ \\
\hline No & 16.7 & 60.7 & 47.6 & 10.0 & 40.7 & \\
\hline \multicolumn{7}{|l|}{ Auditing frequency } \\
\hline Once a year & 50.0 & 30.0 & 14.3 & 20.0 & 29.6 & $16.469(0.521)$ \\
\hline Twice a year & 33.3 & 10.0 & 9.5 & 40.0 & 11.1 & \\
\hline Three times a year & 16.7 & 10.0 & 19.0 & 20.0 & 18.5 & \\
\hline Other & 0 & 10.0 & 23.8 & 10.0 & 7.4 & \\
\hline None & 0 & 40.0 & 33.3 & 10.0 & 33.3 & \\
\hline
\end{tabular}

Table 3. Traceability availability and efficiency.

\begin{tabular}{|c|c|c|c|c|c|c|}
\hline & \multicolumn{5}{|c|}{ Type of Business } & \multirow[t]{2}{*}{ Chi Square } \\
\hline $\begin{array}{c}\text { Availability of traceability } \\
\text { procedure }\end{array}$ & Hotels & Restaurants & Manufacturers/Processors & Hospitals & Schools & \\
\hline Yes & 66.7 & 30.0 & 57.1 & 60.0 & 55.6 & $2.962(0.564)$ \\
\hline No & 33.3 & 70.0 & 42.9 & 40.0 & 44.4 & \\
\hline \multicolumn{7}{|l|}{ Traceability in practice } \\
\hline Yes & 0 & 20.0 & 42.9 & 10.0 & 11.1 & $20.120(0.030)$ \\
\hline No & 100.0 & 80.0 & 57.1 & 90.0 & 90.0 & \\
\hline \multicolumn{7}{|l|}{$\begin{array}{c}\text { Time taken to complete } \\
\text { traceability }\end{array}$} \\
\hline 4 hours & 16.7 & 0 & 23.8 & 20.0 & 14.8 & $11.396(0.935)$ \\
\hline $4-7$ hours & 0 & 10 & 0 & 10.0 & 7.4 & \\
\hline $6-10$ hours & 0 & 0 & 9.5 & 0 & 3.7 & \\
\hline$>10$ hours & 0 & 0 & 4.8 & 0 & 3.7 & \\
\hline$>24$ hours & 0 & 10 & 9.5 & 0 & 7.4 & \\
\hline Never & 83.3 & 80.0 & 52.4 & 70.0 & 63.0 & \\
\hline
\end{tabular}

procedures across the businesses were not significantly different although restaurants were the businesses with the least percentage of documented traceability procedure hence routine traceability checks or trails were also not in place. A hundred percent of the sampled hotels had no routine traceability checks and so were the hospitals and schools with $90 \%$ each on no traceability checks. Manufacturing and processing industries however had lowest figure on unavailability of routine traceability checks. The availability of routine traceability checks across the businesses was significant $(p \leq 0.05)$. Manufacturers/processors were more committed in maintaining traceability and thus quality assurance. This shows limited availability or less knowledge and awareness of traceability systems in the food industry leading to the possible difficulty to trace products as production and food handling in the country is still less controlled along the food chain $[12,16]$. Demonstrating compliance with food safety requirements of the global economy is a prerequisite for success [4], but this was not affirmed as most of the businesses could not complete traceability test within the stipulated 4 hours. Only $23.8 \%$ of the manufacturers/processors, $20.05 \%$ of hospitals, $16.7 \%$ of hotels and $14.8 \%$ of schools could complete their traceability within this time. Thus there was no significant difference within the time the businesses took to complete traceability tests.

\section{Conclusion}

The awareness of traceability systems in the Ghanaian food industry is not totally absent although implementa- 
tion and maintenance is limited to a few businesses across the industry. Personnel in the industry in charge of food safety and hygiene systems are mostly Higher National Diploma holders who have limited food technology backgrounds to be able to take absolute responsibility for implementing and maintaining the needed legislative and standard quality systems required. It is recommended that more short courses for training personnel in the food industry be designed for workers by the appropriate institutions with the needed legislative backing while more students from the Senior Secondary Schools are encouraged to take food science and food manufacturing and technology related programmes to help improve on the current situation.

\section{REFERENCES}

[1] T. G. Karippachevil, D. L. Rios and L. Srivastava, "Global Markets, Global Challenges, Improving Food Safety and Traceability while Empowering Smallholders through ICT," 2012. www.ictinoagriculture.org

[2] E. Golan, B. Krissoff, F. Kuchler, L. Calvin, K. Nelson and G. Price, "Traceability in the US Food Supply Chain," Agriculture Economic Report, 2004, 56 p. www.ers.usda.gov

[3] Z. Gyori, I. Mitlasovszky, B. Kerekes, J. Solyom and Z. S. Nemeth, In: C. Andrea, "Opportunities of Integrating Supply Chain Quality Management and Product Development with Formulation Systems in Compound Feed Manufacture," Quality Assurance and Safety of Crops and Food, Vol. 3, 2011, pp. 82-88.

[4] L. D. Mensah, "Developing of Food Safety Capability in Ghana to Enhance Access to the Global Food Manufacturing Value Chain," Ph.D. Thesis, Cranfield University, Northampton, 2012. http://dspace.lib.cranfield.ac.uk

[5] "Codex Alimentarius Commission, Food Hygiene," 4th Edition, WHO/FAO, Rome, 2009.
[6] C. Andrea, "Opportunities of Integrating Supply Chain Quality Management and Product Development with Formulation Systems in Compound Feed Manufacture," Quality Assurance and Safety of Crops and Food, Vol. 3, No. 2, 2011, pp. 82-88.

[7] C. Knight, "Traceability in the Food and Feed ChainSystem Requirement for System Design and Implementation," Campden BRI, Glaucestershire, 2012. www.campden.co.uk

[8] S. Sansawat and V. Muliyil, "Comparing Global Food Safety Initiative Recognized Standards," 2012.

[9] L. Barbara, "What Is Food Safety Chain Management," Position Paper, Safetychainsoftware, Inc., 2012. www.foodsafetychain.com/resources

[10] P. N. T. Johnson, K. I. Tomlins, C. Oduro-Yeboah, C. Tortoe and E. T. Quayson, "A Case Study to Develop an Appropriate Quality Assurance System for Two CassavaBased Convenience Foods in Ghana," Internet Journal of Food Safety, Vol. 10, 2008, pp. 81-84.

[11] P. F. Ababio and D. D. Adi, "Food Safety Practices among Food Handlers in the Kumasi Metropolis of Ghana," Internet Journal of Food Safety, Vol. 14, 2012, pp. 35-43.

[12] Ghana New Agency, "Food Processing Companies over Look Self Inspection-FDB,” 2012. www.ghanaweb.com

[13] S. Sefa-Dedeh, "Ghana-Overview of Food Safety Situation in Africa-Country Position," Go-Global Conference, Accra, 27 April 2009, pp. 1-58. www.goglobalnetwork.eu

[14] Food Standard Agency, "Food Hygiene a Guide for Businesses," Food Standard Agency, England, 2005.

[15] Ghanaweb, "Ghana Regions," 2012. http://www.ghanaweb.com/GhanaHomePage/geography/r egion.php

[16] Food and Drugs Board, "Food and Drugs Act, PNDC Law 3058," 2012. www.epa.gov.gh 